\title{
DOES MULTICULTURALISM-BASED LITERARY APPRECIATION WITH CLIL APPROACHABLE TO REINFORCEMENT CHARACTER EDUCATION FOR STUDENT?
}

\author{
Gallant Karunia Assidik ${ }^{1}$, Firstya Evi Dianastiti ${ }^{2}$ \\ \{gka215@ums.ac.id ${ }^{1}$, firstya@untidar.ac.id $\left.{ }^{2}\right\}$ \\ ${ }^{1}$ Universitas Muhammadiyah Surakarta, Kartasura, Indonesia \\ ${ }^{2}$ Universitas Tidar, Magelang, Indonesia
}

\begin{abstract}
Internalizing the understanding of the character and multicultural educations is a mandatory matter that must always be established in the learning process to prevent nation disintegration. As an alternative, literature appreciation can be conducted with the Content and Language Integrated Learning (CLIL) approach. In the CLIL approach, the theory of teaching material selection used in learning activities refers to the concept of $4 \mathrm{C}$ (content, communication, cognition, culture). Through the $4 \mathrm{C}$ concept, the variety of teaching materials and literary texts used will be better in grading and comply with the vision to internalize character education and multiculturalism to the learners. Based on its literary analysis, Komik AKU KPK, Tiga Pahlawan Tanpa Tanda Jasa, and Anak Indonesia Hebat contain the values of religious, multicultural, love, faith, responsibility, tolerance, hard work, independent, creative, curiosity, and social care character, that can be applied as a suitable basis for students life development.
\end{abstract}

Keywords: literary appreciation; character education reinforcement; multiculturalism; Content and Language Integrated Learning (CLIL)

\section{INTRODUCTION}

Character education or moral education is always an interesting issue to review. Under the Decree of Indonesian Minister of Education and Culture, the implementation of the 2013 Curriculum targets the achievement of student's character, competence, and literacy. Competence does not merely mean the student's ability in certain subjects but also emphasizes the development of critical thinking skills, creativity, communication, and collaboration. Besides, the expected literacy to realize is productive in reading and writing, numeracy, science, communication and information technology, finance, and cultural and citizenship. As for the aspect of the character, the revised edition of the 2013 Curriculum by the Government focuses on four main characters: religious, nationalist, independent, cooperation, and integrity. Educators have tasks to collaborate, gather, and implement these three key aspects of school learning. 
As the basis of three key aspects in the 2013 Curriculum, the character becomes the inseparable focus of learning. Considering the development of technology and modernization in all lines, character education is one of the foundations needed to create not only intellectual but also the well-moral young generation of Indonesia. Nowadays, the role of the school as a moral (character values) educator becomes more vital since the learners do not get sufficient moral education from the parents, places of worship, and society [1]. In Indonesia, character education is correlated with the concept of multiculturalism. Multiculturalism is the term used to describe the view of the world diversity or cultural policy that emphasizes the acceptance of diversity, plurality, as the ultimate reality in the society concerning the social values, sociocultural and political systems they hold [2].

It is hard to enforce character education and the understanding of multiculturalism independently. It should be supported and integrated into all aspects of formal and non-formal education, as well as in curriculum applied in schools. The integration of character values has been more detailed in the 2013 Curriculum. Besides, Bahasa Indonesia also receives a distinctive position in the 2013 Curriculum in which it is not only positioned as an independent knowledge but also functioned as a knowledge courier that is integrated with the development of attitudes, the implementation of character values, and learning material. Therefore, Bahasa Indonesia, with its existing learning material, including literary works, is considered to be able to support its function as a knowledge courier as well as a means of reinforcing character education and teaching an understanding of multiculturalism.

Bahasa Indonesia's subject cannot be separated from literary works. The word Sastra (literature) in the Indonesian language derives from Sanskrit. The root word sas- means directing or teaching. The suffix -tra denotes a tool or a means. Hence, Sastra means an instrument of teaching, giving guidance [3]. Literature as a manifestation of community life will help learners to absorb life experiences and values delightfully. All elementary to senior high school students need to get an understanding of multiculturalism and character values. Character education will be useful in optimizing their role as a member of society and God's creature.

However, the internalization of character values and multiculturalism to the learners cannot be taught by a binding doctrine system. The internalization of character values and multiculturalism must be performed through a variety of relevant means and media, such as literary works or literature. One of the literary functions is dulce et utile (sweet and useful). It means that literature can be used as a means of recreation as well as education [4]. Literature is an imaginative human work by language as the media and has a dominant aesthetic value [5].

In a core point, literary works serve as a media of communication between the author and readers. Literary works are human creations that have content, in the form of messages and meanings depicted in life (the world in words) by a media of aesthetic language, which is a beautiful language and different from everyday language. Besides, literature is often placed as a social portrait [6]. Literature reveals the condition of a society at a specific time. Hence the reflection of public behavior in literary texts can be used as a media of implementing character values and multiculturalism to the learners.

The use of literary works as an alternative media in reinforcing character education is supported by the application of the Content and Language Integrated Learning (CLIL) approach in learning Bahasa Indonesia. In the CLIL approach, the theory of teaching material selection used in learning activities refers to the concept of 4C (content, communication, cognition, culture). Through the $4 \mathrm{C}$ concept, the choice of teaching materials and literary texts used will be better in grading and comply with the vision to internalize character education and multiculturalism to the learners. The $4 \mathrm{C}$ concept contained in the CLIL approach also supports 4C competencies in the 2013 Curriculum, namely critical thinking, creativity, communication, 
and collaboration. Both of these $4 \mathrm{C}$ concepts are the basis for measuring the readability and suitability of literary texts that will be used in learning without putting aside the vision to internalize character education and multiculturalism to students.

Character education and multiculturalism become one of the research themes that are never dry to be studied. With the development of globalization and modernization as well as the increasingly plural society's growing demands, learners must be given an understanding of the issues of multiculturalism. However, the perception of multiculturalism is also not well understood by teachers. The results point out that teachers focus primarily on religious diversity when they are asked about their understanding of multicultural education [7].

Research that focuses on the analysis of teachers is also conducted by Alismail (2016), who conducted research on teachers' perceptions of multicultural education in schools. The study concluded that multicultural education is an essential and necessary concept. Conservatives see multicultural education as a means of integrating students into broader society. Teachers need to understand multiculturalism to provide equal education for all students. The literature here suggests that many teachers feel they need more training in multicultural education because of the diversity of their classrooms [8].

Besides, character education and multiculturalism, in fact, also have relevance to the effort to improve the thinking ability of learners. Assidik (2017) reviews the integration of media literacy to enhance Higher Order of Thinking Skills (HOTS) and as a means of strengthening the character education of learners. Through the ability to understand, analyze and deconstruct image and news submitted by the media, is expected to trigger reasoning power and high-order thinking (HOTS) as well as can be used as a means of strengthening character education [9].

Indonesia, as the Unity of Diversity of Bhineka Tunggal Ika, also significantly upholds the quality of education through the Implementation of Curriculum 2013. In the text-based Curriculum 2013, the government seeks to integrate character education and multiculturalism in school learning. Dianastiti (2017) explained that character education facilities could be done through the use of interactive learning media [10]. Based on the literature review that has been done, it is concluded that character education and multiculturalism should be an integral part of the process and various materials in teaching and learning activities in schools. As it proves, through the integration of learning in formal education, there is a transfer of knowledge and understanding of the values of character and multiculturalism.

Research on the implementation of character education through literature has been done by Fethi Turan and Ilkay Ulutas (2016) in a study entitled Using Storybooks as a Character Education Tools. They conclude that the study results show that character education is important for the teachers; teachers use picture storybooks that support character education. However, they find themselves an education, and ideas like drama, play, question-answer, and brainstorming are much preferred for an effective character education [11].

Then, Nita Novianti (2017) conducted research titled Teaching Character Education to College Students Using Bildungsromans. The results show that most students have successfully identified the virtues in the novel and can relate to the characters and their events [12]. Setijani's research (2017) supports the hypothesis that literature can be one of the media of characterization and multiculturalism. This research is aimed at describing the value of education: (1) to appreciate the difference ethnicity; (2) respect differences religion; (3) respect differences race; and (4) respect differences of culture depicted in the novel Different: when differences are not a written barrier by Irma T. Lestari. The study concludes that the novel, as one form of literary work, has character values that can be absorbed by learners [13].

Not only young and adult novels, but children's storybook is also a reflection of life in which contained the values of characters that can be absorbed by primary school students. A good 
children's fiction book is a storybook that leads and departs from a child's point of view. [14] The child's story is about the various problems that may occur in a child's life so that the child can understand his world. When reading children's stories, elementary school students can understand, identify, and develop their fantasies according to what they read. The final estimate of the child's story reading activity is expected for a child to feel happy, satisfied, and able to gain valuable lessons from the story that has been read.

CLIL describes an evolving approach to teaching and learning where subjects are taught and studied through the medium of a non-native language. The experience of learning subjects through the medium of a non-native language is more challenging and intensive as there are more knowledge and skills in different areas of the curriculum. In CLIL, learning a curriculum of the range of educational contexts [15]. CLIL is currently enjoying a cross-curricular form [16]. In the CLIL approach, the theory of teaching material selection used in learning refers to the $4 \mathrm{C}$ concept (content, communication, cognition, culture). The content relates to how the content of a text and its relation to the material to be taught. In addition to containing the character and multicultural values, the text presented should also be appropriate to the developmental phase of the child's age. Selection of communication aspects associated with the level of legibility for learners. The next aspect is the level of cognition (cognition) of the learners. The last aspect that is not less important is that every text should pay attention to the culture (culture) learners. Stories submitted in such a way should be familiar with the life of the community of learners, so that series of stories and internalization of the values contained in the text is easier to do, including the subject of multicultural values to be conveyed.

Some of the advantages of CLIL learning are; 1) introducing broader cultural contexts; 2) preparing students to face international era; 3) accessing International Certification and enhancing school profiles; 4) improving overall and specific language competencies; 5) making for future study and/or work life of participants educate, 6) developing multilingual interests and attitudes, 7) diversifying methods and forms of classroom teaching and learning, and 8) improving motivation of learners.

\section{METHOD}

This research method is a qualitative descriptive study. The instrument used is the researcher himself (human instrument). The source of this research data are books; Komik AKU KPK, Tiga Pahlawan Tanpa Tanda Jasa, and Anak Indonesia Hebat. The data collection technique used in this study was the skillful listening free technique.

\section{RESULT AND DISCUSSION}

Based on the analysis, the result and discussion consist of (a) graded literature appreciation as an effort to reinforce character education and (b) moral reflection.

\section{Graded Literature Appreciation As An Effort To Reinforce Character Education}

For a very multicultural society, as in Indonesia, internalizing the understanding of the character and multicultural educations is a mandatory matter that must always be established in the learning process to prevent nation disintegration. As an alternative, literature appreciation can be conducted with the Content and Language Integrated Learning (CLIL) approach. Literary appreciation is an attempt to enjoy literary works. The word "appreciate" derived from the Latin word appretio or appretiatus, which means an activity of assessing or appraising. 
The ability to appreciate is accrued through processes. In conducting an assessment or interpretation, it requires a capability supported by knowledge, experience, and artistic ability. Furthermore, literary appreciation activities can develop learner's mindset, reasoning, insight, imagination, appreciation, and critical attitude in looking at various problems. This appreciation activity fosters learner's sensitivity to the values contained in the literary text to understand or at least enjoy the details of art in the literature and receive it as it should.

The term appreciation implies (1) a recognition through the feeling or inner sensitivity, and (2) an understanding and acknowledgment of the beauty values expressed by the author [17]. This literary appreciation activity is expected to encourage the learners to appreciate more the moral values and multiculturalism contained in literary texts. Once the learners are able to live up to these values, it is expected that these values can be applied and internalized in everyday life.

In the process of appreciation, learners can be divided into several stages: (1) the stage of fondness, indicated by a sense of love and be interested in literary books, (2) enjoying stage, starting feeling and enjoying the creation of literature as the understanding begins to grow, (3) reacting stage, there is a willingness to express opinions about the work of literature enjoyed, for example by writing, (4) productive stage, that is a starting point to produce literary works [1].

Graded literary appreciation highlights that literary texts used as learning media should observe the theory of teaching material selection in CLIL, i.e., the 4C concept (content, communication, cognition, culture). Based on the analysis results, the examples of literary text that can be used as a learning media in literary appreciation or as a reading material in the school literacy movement selected by considering the concept of $4 \mathrm{C}$ and the internalization of character values and multiculturalism are stated below. The literary texts used as learning media utilize literacy reading material published by Kemendikbud.

Table 1. Literary Works Contain Character Values and Multiculturalism

\begin{tabular}{|c|c|c|}
\hline Literary Text & Character Values & Level of Readability \\
\hline $\begin{array}{l}\text { Title: Komik AKU KPK (Aksi } \\
\text { Komik Untuk KPK) } \\
\text { Publisher: KPK }\end{array}$ & $\begin{array}{l}\text { Character values: anti- } \\
\text { Corruption, religious, } \\
\text { multicultural, responsible, } \\
\text { tolerance }\end{array}$ & $\begin{array}{l}\text { Readable for junior high school } \\
\text { - high school students }\end{array}$ \\
\hline $\begin{array}{l}\text { Title: Tiga Pahlawan Tanpa } \\
\text { Tanda Jasa } \\
\text { Author: Faturrahman Arroisi, } \\
\text { Wida Ayu P. } \\
\text { Publisher: Kemendikbud }\end{array}$ & $\begin{array}{l}\text { Character values: religious, } \\
\text { discipline, hard work, the } \\
\text { spirit of nationality, loving } \\
\text { the motherland, multicultural }\end{array}$ & $\begin{array}{l}\text { Readable for upper grades of } \\
\text { elementary school students }\end{array}$ \\
\hline $\begin{array}{l}\text { Title: Wisata Kuliner Bersama } \\
\text { Nenek } \\
\text { Author: Unsiyah Anggreini, } \\
\text { Septinata C. P } \\
\text { Publisher: Kemendikbud }\end{array}$ & $\begin{array}{l}\text { Character Values: } \\
\text { multicultural value, curiosity, } \\
\text { social care, creative value }\end{array}$ & $\begin{array}{l}\text { Readable for lower grades of } \\
\text { elementary school students }\end{array}$ \\
\hline $\begin{array}{l}\text { Title: Dito dan Kisah-Kisah } \\
\text { Teladan } \\
\text { Author: Fitria Nia Dikasari, } \\
\text { Titin Indriarti } \\
\text { Publisher: Kemendikbud }\end{array}$ & $\begin{array}{l}\text { Character Values: } \\
\text { multicultural, religious, } \\
\text { independent, hard work, } \\
\text { nationalist, loving the } \\
\text { motherland, curiosity }\end{array}$ & $\begin{array}{l}\text { Readable for upper grades of } \\
\text { elementary school students, } \\
\text { junior high school students }\end{array}$ \\
\hline
\end{tabular}




\section{Moral Reflection}

Moral reflection is essential to build the cognitive side of the character. Moral reflection becomes an important part of ourselves that allows us to make moral scales on our own and others' behaviours [18]. Moral reflection has six aspects, as follows. (1) Being morally conscious sees the moral dimension from various situations in life. Moral values are at stake. (2) Having an understanding of objectively useful moral values (e.g. being respectful and responsible) and how to apply them in concrete situations. (3) Being able to take others' perspective. (4) Being able to think morally - understands why specific actions are morally better than others. (5) Being able to make moral decisions based on mature thinking, considers all alternatives, consequences, and moral values at stake. (6) Having self-understanding, including the capacity to self-critics.

\section{Character of Being Religious}

The first character that forms the basis of other characters is being religious. Religious character is found in all examples of literary texts contained in Table 1 . The values of religious character can be found in the following data.

Data 1. Kemampuan Musa, si bocah kecil yang telah mampu menghafal Alquran itu membuat bangga orang tuanya dan masyarakat Indonesia. Yang lebih penting lagi, membaca Alquran merupakan ibadah. Anak yang membaca Alquran akan mendapatkan pahala dari Allah. Wah, senangnya bila kita rajin membaca Alquran. (Anak Indonesia Hebat, pg. 6-7)

Data 2. "Waaahhhh.... Asyik, hidangan spesial dari Mamak tercinta," ujarku sambil menggoda Mamak. "Ini juga berkat Ainun. Ainun kecil-kecil begini sudah pandai membantu orang tua. Ibu Ainun pasti bangga pada Ainun," ujar Mamak. Ainun tersenyum. "Aamiin." "Hari ini siapa yang pimpin doa?" tanya Bapak. “Dito, Pak,” ujar Bang Dika. (Dito dan Kisah-Kisah Teladan, pg.39)

Data 3. Teman-teman, beberapa di antara teman kita ada yang memiliki keistimewaan. Mereka adalah anak yang memiliki kemampuan tertentu atau anak yang memiliki keterbatasan dan kebutuhan khusus, seperti anak yang tidak dapat mendengar, tidak dapat melihat, atau kelainan lainnya. Namun, meskipun memilliki keterbatasan, mereka juga memiliki bakat dan kelebihan lain yang dianugerahkan Tuhan Sang Maha Pencipta. Banyak di antara mereka yang memiliki prestasi hebat, salah satunya adalah Stephanie Handojo. (Anak Indonesia Hebat, pg. 33-34)

Data 1 and data 2 is important for students' understanding of the first point of Pancasila, "Ketuhanan yang Maha Esa"or "Belief in the one supreme God". Data 1 also teaches the virtues of helping and respecting parents. When these values are taught through stories, the students no longer consider them as compelling commands.

Data 3 provides students with an understanding that God, the supreme Creator, has given the best life for every human being. In addition to teaching gratefulness, Data 3 also reflects 
mutual tolerance and cooperation in life that leads students to help each other, more specifically, to help friends who have special needs and limitations. In literary appreciation, Data 3 can be used by teachers as a means to explain that high spirit and integrity are required in realizing the student's dreams.

The rise of many bullying cases among students indicates the urgency of embedding these religious character values. Therefore, literary texts with suitable readability to student's cognitive and psychological levels will help convey this understanding without pressuring the students. Religious values will be a strong foundation for attitudes and basic values as a guide for the students in determining positive or negative behaviour in daily lives.

\section{The character of Being Nationalist}

The nationalist character values contained in literary texts are proven in the following data.

Data 4. Stephanie memiliki semangat yang sangat tinggi. Ia tidak mau kalah dengan teman-teman lainnya. Ia terus berlatih dan belajar agar dapat menjadi anak yang mandiri. Hal ini juga berkat dukungan sang ibu yang telaten dan selalu membimbingnya dengan penuh kasih sayang. Dukungan dari keluarga, guru-guru, dan teman-temannya sangat membantunya untuk menjadi orang yang percaya diri. (Anak Indonesia Hebat, pg. 34)

Data 5. Dito mampu membawa nama baik sekolahnya. Yang lainnya bisa belajar dari Dito bahwa kita tidak boleh takut untuk bermimpi. Yang terpenting adalah berdoa dan berusaha. Tapi di samping itu, kita harus tetap bersyukur baik menang maupun kalah. Memberi itu lebih baik dibandingkan meminta. Lakukan sesuatu yang baik untuk keluargamu, agamamu, sekolahmu dan negaramu," ujar Bapak singkat. (Dito dan Kisah-Kisah Teladan, pg. 33)

Data 6. Meskipun kami berbeda agama dengan Fandi, Bapak dan Mamak selalu mengajarkan arti toleransi dalam hidup bertetangga agar tercipta kedamaian dalam hidup berdampingan. Seperti semboyan Indonesia: Bhinneka Tunggal Ika, yang artinya berbeda-beda tetapi tetap satu jua. (Dito dan Kisah-Kisah Teladan, pg. 42)

Data 4, data 5, and data 6 reflect students' daily lives who meet various ethnics and religions. In data 4 and data 5 , the main character did not exclusively limit his friendships at school. The main character's attitudes in data 4 and data 5 can be good role models for all young Indonesians. It portrays a message that if minor ethnics can adapt to the culture of major ethnics, differences in ethnicity, race, and religion do not become obstacles in socializing and achieving their goals.

Data 6 reflects the mutual respect between school members, both teachers, and students, to the students who hold different religious beliefs. Schools should develop religious lives that are believed by all students. The school strives to foster a character of being nationalist to lead every student to recognize other's religions' existence. Implicitly, the data is also a means of internalizing a value that Indonesia is a country of Unity in Diversity. 


\section{The character of Being Independent}

The third character value emphasized in the 2013 Curriculum is independence and hard work. Internalizing independence and hard work are important to prepare the students to face the world of work. The era of the $21^{\text {st }}$ century demands qualified workforces capable of overcoming various work challenges. Both character values can be found in the following data.

Data 7. Ayah Alif tidak berputus asa. Sang ayah memberikan semangat pada Alif untuk terus berlatih. Ayahnya kemudian menunjukkan video rekaman teknik gerakan permainan bola dan meminta Alif belajar menirukannya. Alif sangat tertarik, ia pun tekun berlatih menirukan gerakan-gerakan permainan bola itu hingga berhasil memainkannya. (Anak Indonesia Hebat, pg. 11)

Data 8. Pada saat berusia enam tahun, ayahnya kembali mendaftarkan Alif pada sekolah bola. Saat itu sang pelatih sangat tertarik melihat bakat dan kepintaran Alif bermain bola. Alif langsung diterima, dan bahkan mendapatkan bea siswa. Di sekolah bola itu Alif semakin mengasah bakat dan keterampilannya bermain bola. Ia juga belajar bekerja sama dalam sebuah tim dengan teman-temannya. (Anak Indonesia Hebat, pg. 12)

Data 9. "Ibu yang kusayangi, Pak Hadi mengajarkan kepada saya bahwa manusia tidak boleh berhenti menuntut ilmu sampai akhir hayatnya. Oleh karena itu, saya tidak akan berhenti belajar. Saya meminta restu Ibu untuk mencari cara lain agar tetap bisa belajar." (Tiga Pahlawan Tanpa Tanda Jasa, pg.21)

Data 10. Aku mempunyai dua malaikat, yaitu Bapak dan Mamak. Bapakku seorang buruh tani di sebuah kebun lada milik Pak Hadi, salah satu orang terkaya di kampungku. Setiap hari Bapak ke kebun pukul tujuh pagi dan pulang di saat senja. Bapak memang hanya tamat $\mathrm{SD}$, tapi Bapak tahu banyak hal. Bapaklah yang mengajari kami banyak hal serta memotivasi kami untuk terus belajar agar bisa meraih mimpi-mimpi kami. (Dito dan Kisah-Kisah Teladan, pg.2)

Data 7 until data 10 represent parents' messages for children to learn to be independent and work hard even though they are still young. With the example of a young football player, the literary text leads to the internalization of independence embedded from an early age. Following the aspect of content in $4 \mathrm{C}$, the data can be used at the elementary school level. However, it is less suitable for high school students because the exemplified independence in this data is still in the form of daily activities that are not relevant to the demands of independence of junior and senior high school students.

\section{Character of Integrity}


The next character value is integrity and being responsible, which is represented in a literary text entitled $A K U K P K$. These short stories and comics are suitable for students in elementary school, junior high, and also senior high school.
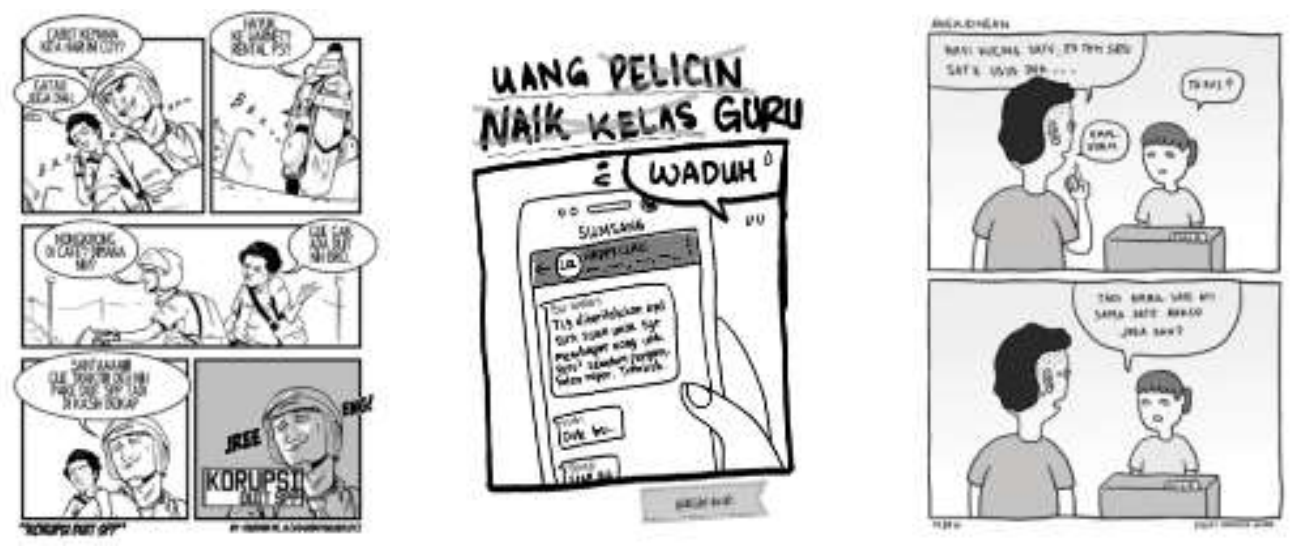

Fig. 1. Comics from $A K U K P K$

Although it can be used as a learning media at all levels of school, data 8, data 9, and data 10 will be accepted differently by students at each level. Students in elementary school have a limited understanding that corruption is the same as stealing. Still, students in junior high and senior high school have reached the level of understanding the implicit meaning that someone with a high cognitive level is not necessarily successful in managing attitude, spirituality, and integrity.

This is related to the evaluation of literary appreciation used by teachers. Based on the decree of the Indonesian Minister of Education and Culture, the implementation up to the evaluation process of each subject in the 2013 Curriculum must be based on HOTS. By using data 9 and 10 , teacher's questions for elementary school level are limited only to assess the cognitive level of understanding. However, following HOTS demands, the questions used in the assessment at the junior high and senior high school are at the application and reasoning level. The questions given by the teacher and the discussion process in appreciating literary texts in the data above are expected to stimulate the internalization of the character of integrity and being responsible.

Literary appreciation is employed as a means of moral reflection. Children perceive the values contained in literary works, and unconsciously reconstruct their attitudes and personality. Literature not only serves as a means of character values implementation but also stimulates the children's creative imagination to think critically through the curiosity of the story plot and the metaphors contained in it. Based on the reality that literature is created by members of the community, telling about the society, and read by the society, literature will automatically accommodate character values that can be a learning tool for learners. Based on the literary analysis, Komik AKU KPK (Aksi Komik Untuk KPK), Tiga Pahlawan Tanpa Tanda Jasa, Wisata Kuliner Bersama Nenek, and Anak Indonesia Hebat contain the values of religious, multicultural, love, faith, responsibility, tolerance, hard work, independent, creative, curiosity, and social care, that can be applied as a suitable basis for students life development. 


\section{CONCLUSION}

CLIL is not a new thing in language teaching. The content and language integration approach has been used for decades with different labels. CLIL has long known as task-based learning and teaching, an "immersion" program in Canada and Europe, a bilingual education program in the US. Language teaching experts agree that CLIL is a more realistic development of communicative language teaching that develops communication competence than others. Thus it can be assumed that the direction of further development of Competence-Based Curriculum (2006) is a curriculum based on CLIL. This is the primary reference for the 2013 Curriculum.

The success of CLIL (which integrates content and language) in Europe, USA and Canada is based on the result of second language acquisition research (Krashen (1982), Lightbown and Spada (2006), Swain (2000), Yolanda Ruiz de Zarobe, Rosa María Jiménez Catalán (2009), Jonathan Savage (2011). The results of the study show that CLIL creates a natural state in language learning, provides a clear purpose of language use in the classroom, positively impacts because it emphasizes more meaning than form, and drastically increases the number of targeted language exposure. Four prominent results of this study is that language teaching within the CLIL focuses on the meaning of language rather than the form of language. Language has a clear and understandable meaning when used in a real context. The themes designed according to student needs can be a real context of language use.

The internalization of character values and multiculturalism to the learners cannot be taught by a binding doctrine system. The internalization of character values and multiculturalism must be performed through a variety of relevant means and media, such as appreciating literary works. The selection of literary works to use is following the guidelines in the Content and Language Integrated Learning (CLIL) approach, called as the concept of 4C (content, communication, cognition, culture). Based on the literary analysis, Komik AKU KPK (Aksi Komik Untuk KPK), Tiga Pahlawan Tanpa Tanda Jasa, Dito dan Kisah-Kisah Teladan and Anak Indonesia Hebat contain the values of religious, multicultural, love, faith, responsibility, tolerance, hard work, independent, creative, curiosity, and social care, that can be applied as a suitable basis for students life development.

\section{REFERENCE}

[1] T. Lickona, Pendidikan Karakter,Panduan Lengkap Mendidik Siswa Menjadi Pintar dan Baik (Diterjemahkan dari Buku Educating for Character). Bandung: Nusa Media, 2013.

[2] A. Azra, Identitas dan Krisis Budaya, Membangun Multikulturalisme Indonesia. Jakarta: Pustaka Indonesia, 2007.

[3] A. Teeuw, Pengantar Ilmu Sastra. Bandung: Pustaka Jaya, 1984.

[4] R. dan A. W. Wellek, Theory of Literature. New York: Harcourt, Brace, and World, 1956.

[5] M. S. Mahayana, "Perempuan yang Tertindas Perkembangan dan Perbandingan Novel Indonesia, Malaysia, dan India," J. Kaji. Sastra Jentera, pp. 11-28, 2011.

[6] M. V. H. Agridag, Orhan, Michael S. Merry, "Teachers Understanding of Multicultural Education and The Correlate of Multicultural Content Integration in Flanders," Educ. Urban Soc., vol. 48, pp. 556-582, 2016.

[7] H. A. Alismail, "Multicultural Education: Teachers Perception and Preparation," J. Educ. Pract., vol. 7, pp. 139-146, 2016.

[8] G. K. Assidik, "Integrasi Literasi Media sebagai Sarana Peningkatan Higher Order of 
Thinking Skill (HOTS) dan Penguatan Pendidikan Karakter (PPK) Peserta Didik,” in Prosiding International Conference Language Literature and Teaching. Konferensi Bahasa dan Sastra Bahasa 2, 2017, pp. 398-406.

[9] F. E. Dianastiti, "Pemanfaatan Film Karya Peserta Lomba Film Pendek Kemendikbud sebagai Media Pembelajaran Bahasa Indonesia dan Sarana Pendidikan Karakter Peserta Didik," in Prosiding Konferensi Nasional Bahasa dan Sastra IV, 2017, pp. 178-181.

[10] I. U. Turan, Fethi, "Using Storybook as a Character Education Tools," J. Educ. Pract., vol. 7, pp. 169-176, 2016.

[11] N. Novianti, "Teaching Character Education to Collage Student Using Bildungsromans," Int. J. Intruction, vol. 10, pp. 255-272, 2017.

[12] Setijani, "Nilai-Nilai Pendidikan Multikultural Novel Different: Ketika Perbedaan Bukan Sebuah Penghalang Karya Irma T. Lestari," Ling. Fr. J. Bahasa, Sastra,dan Pengajarannya, vol. 1, pp. 63-80, 2017.

[13] B. Nurgiyantoro, Sasrta Anak: Pengantar Pemahaman Dunia Anak. Yogjakarta: Gadjah Mada University Press, 2005.

[14] ESOL, Teaching Konwledge Test (TKT), Content and Language Integrated Learning (CLIL). United Kingdom: University of Cambridge, 2010.

[15] E. Harrop, Content and Language Integrated Learning (CLIL): Limitations and Possibilities. 2012.

[16] N. Haryati, Paparan Kuliah Apresiasi Prosa. Semarang: UNNES, 2007.

[17] Zulfadhli, "Pengajaran Apresiasi Sastra di Sekolah Dasar: Sebuah Pengantar," J. Bhs. Sastra dan Seni, vol. 6, 2005.

[18] Y. Widiyono, "Nilai Pendidikan Karakter Tembang Campursari Karya Manthous," J. Pendidik. Karakter Tahun III, pp. 231-239, 2013. 